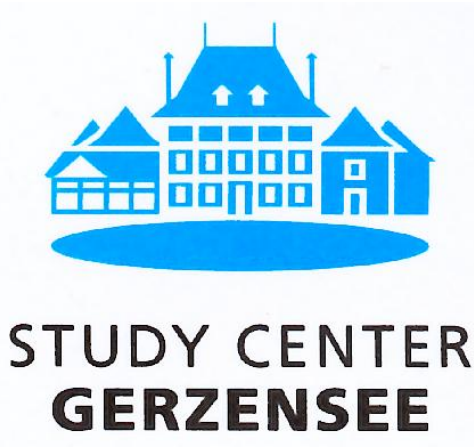

\title{
The Journal Rankings of Central Banks
}

\author{
Emanuel Kohlscheen
}

Working Paper 11.05

This discussion paper series represents research work-in-progress and is distributed with the intention to foster discussion. The views herein solely represent those of the authors. No research paper in this series implies agreement by the Study Center Gerzensee and the Swiss National Bank, nor does it imply the policy views, nor potential policy of those institutions. 


\title{
The Journal Rankings of Central Banks
}

\author{
Emanuel Kohlscheen ${ }^{* \dagger}$
}

\begin{abstract}
This paper analyzes the citation patterns of the central banks of the 15 largest monetary areas of the world that had an active working paper series in 2010. It proceeds to construct a novel journal ranking that is more suited for monetary authorities than the academic journal rankings currently in vogue. We report individual country rankings as well as the global rankings. While important regional differences emerge, the Journal of Monetary Economics, the American Economic Review, the Journal of Money, Credit and Banking and the Journal of Finance stand out as the top outlets in the global ranking. Sweden's Riksbanken appears to be the monetary authority that is most finely tuned with academia, followed by the European Central Bank.
\end{abstract}

JEL Classification: A11, E50, E58

Keywords: central banks; citations; economic journals; rankings

\footnotetext{
* Research Department, Central Bank of Brazil.

${ }^{\dagger}$ The views expressed in this work are those of the author and do not necessarily reflect those of Banco Central do Brasil or its members. I thank Raphael Auer, Egil Matsen, Dirk Niepelt and Benjamin Tabak for comments and suggestions.
} 


\section{Introduction}

While academic journals have long been an important means of knowledge dissemination in the scientific community, more recently central banks have increasingly turned to articles published in academic journals as a basis for their growing research efforts. At the same time, central bank staff have occasionally become not only consumers, but also producers of articles that are published in top journals. The creation of journals that are devoted to the topics that are of interest to central bankers is a clear indication of the intensification of this phenomenon. Arguably, on top of providing the means of access to a wide international readership, the publication of research in highly rated peer-reviewed outlets may be seen as a certification of the quality of the research effort. However, at the same time that there seems to be a certain convergence of researchers that are based in central banks and academia, it should be recognized that the interests of these two groups do not necessarily coincide: a paper that is considered of high relevance in academia may not attract the same level of attention in central banks. The converse is equally true. One implication is that, to the extent that relevance diverges between the two professional groups, journal rankings that are tailored for academia will be inappropriate impact measuring sticks for central banks and economic practitioners. Against this backdrop, this paper carries out 
a detailed analysis of the citation patterns of the central banks of the 15 largest monetary areas of the world that had an active working paper series in 2010 to construct novel regional and global journal rankings that are more suited for central bankers. ${ }^{1}$ To the best of our knowledge this is the first comprehensive effort in this direction.

A journal ranking of central banks could prove of value for instance for the management of journal subscriptions, research funding decisions, as well as for the analysis of country specific research strengths and weaknesses. While important regional differences emerge, the Journal of Monetary Economics, the American Economic Review, the Journal of Money, Credit and Banking and the Journal of Finance stand out as the top outlets in the global ranking. Of these, only the American Economic Review is usually considered to be a top 5 economics journal in academic circles. Furthermore, the paper is able to obtain an indication of the extent to which research efforts in the different monetary authorities rely on articles that were recently published in academic journals. It finds that Sweden's Riksbank is the most finely tuned with academic research, followed by the European Central Bank.

Relation to the literature. This contribution is related to a wide literature - that goes back at least to Garfield (1972), and, within economics, to Liebowitz and Palmer (1984) - that uses citation count as as a proxy for the impact of research. The core idea in this literature is that citations are

\footnotetext{
${ }^{1}$ Note that the deliberate aim here is to create a ranking that is better suited for a professional group - and not a field ranking. For this reason, the analysis does not attempt to include the research output of monetary economists that are primarily based in academia.
} 
the scientific community's votes for papers that are thought to be of good quality (Laband and Piette (1994)). Hence, the total number of citations that an academic journal gets over a given period is ultimately a reflection of the quality and relevance of that outlet for the profession. The philosophy of this paper is essentially the same - except that we focus on the judgement of the central banking community instead of the academic community.

Recently, journal rankings for academia have been constructed and discussed by Kalaitzidakis et. al. (2003, and then updated in 2010), PalacioHuerta and Volij (2004) and Kodrzycki and Yu (2006) among others. However, an important difference of this study is that - contrary to most of the earlier studies within this literature - we do not restrict the analysis to economic journals a priori. Because of this, the journal ranking that emerges is both, more robust and more comprehensive, including finance journals, such as the Journal of Finance and the Review of Financial Studies. By and large, the analysis carried out here confirms the conjecture that the ranking of journals changes in a clearly noticeable way when one examines citations from a different professional group. Such finding corroborates a conclusion that had already been drawn by Kodrzycki and Yu (2006), when they extended the analysis of the impact of economic journals to the social science and policy literature.

Before we proceed, it should be noted that our view is that publication in academic journals should not be or become an end in itself for central bankers. On this point, we agree with the judgement of Bussiere and Stracca, when they note that although peer review should generally be seen in a positive light 
policy makers should also form their own opinion on the research input that is presented to them and maintain a healthy scepticism vis-à-vis academic publications. (2010, p. 23)

\section{Local Rankings, Academic Intensity and Weights}

To construct the global journal ranking for central banks, we started by assembling the regional rankings. For this, we performed a citation count for the working papers published by the monetary authorities of the 15 largest monetary areas of the world in 2010. We deliberately chose to focus on the central banks of monetary areas, instead of countries, because we wanted to focus on institutions that clearly possess the power to set monetary policy. In the case of a system of central banks we considered the output of the bank that is responsible for monetary policy. For the United States, the research output of the Federal Reserve Bank of New York was considered, whereas in the case of the Eurozone we considered the research output of the European Central Bank. Working paper series were included in the study, provided that they had an output of at least 8 papers in $2010 .^{2}$ All developed countries with a GDP of at least $\$ 250$ bn satisfied this criterion. For countries that had more than 30 working papers published in 2010, we considered the sample of the last 30 papers published within that year. The

\footnotetext{
${ }^{2}$ In the cases of Indonesia, South Africa and Argentina, a working paper series did exist, however, the output of the series in 2010 was well below the threshold.
} 
complete list of Central Banks and working paper series that were included can be found in Appendix A. Once the working papers were selected, we performed the count of all the citations to articles that were published in academic outlets between 2001 and 2010, dividing the total count by the number of working papers that were analyzed. The restriction to citations to recent articles was made to avoid a bias in favor of older academic journals. All in all, the database contains 3,182 citations to papers that were published in a total of 431 academic journals during the last decade.

A few observations are noteworthy: the largest monetary areas for which the respective central bank did not have an active working paper series as of 2010 where the People's Republic of China, Russia and India. All in all, the combined GDP of the 15 monetary areas that are covered in this study was $\$ 44$ trillion in 2010 , or $71 \%$ of world GDP. The largest monetary areas that are included in the study are the U.S. and the Eurozone, whereas the smallest are Norway and Denmark.

Table 1 lists the most cited academic journals for each of the monetary areas of this study, along with the local impact factors - defined as the number of citations one working paper grants to that outlet on average. ${ }^{3}$ The leading influence of the U.S. based American Economic Review and the Journal of Monetary Economics on monetary authorities around the world is unambiguous: while the American Economic Review is the most cited journal in

\footnotetext{
${ }^{3}$ Since the impact factor is typically driven by the top quality papers rather than the average input, even the division of the number of citations by the number of papers that are published by a journal is unlikely to give a satisfactory proxy for the quality of the median paper. We do not perform such division here to avoid biasing the impact factors heavily against general interest journals.
} 
8 of the 15 monetary areas, the Journal of Monetary Economics tops the citations ranking in 5 areas. No other academic journal leads in more than one monetary area. Other important regional differences become evident: for instance, while the Journal of Economic Dynamics and Control appears as 3rd at the ECB and 4th at the Bank of England, it is ranked only at position 43 at the Federal Reserve. This may be an indication that the DSGE revolution did not take hold in the U.S. in the same way that it did in European central banks.

Table 2 shows the average number of (recent) published academic papers that a working paper cites for the 5 monetary authorities that had the highest citation/working paper count. Judging by this measure, the research department of Sveriges Riksbanken is the most finely tuned with academia, followed by the European Central Bank and by Norges Bank. ${ }^{4}$

The global ranking for central banks is constructed via an aggregation of the 15 regional rankings that are listed in Table 1 . To perform such an aggregation, a weighting scheme is needed. The results using two approaches are reported: the equal weights ranking and (our preferred) GDP weighted ranking - where citations can have different values. More specifically, in the latter method, citations by economically important regions are more valuable than citations obtained from the working paper series of smaller monetary areas. In this sense, the GDP weighted global ranking is arguably

\footnotetext{
${ }^{4}$ Clearly, this metric should only be used if research departments did not anticipate its use for international comparisons. We believe that this is indeed a very plausible hypothesis at the present time. Since the analysis was carried out simultaneously for all countries and was unexpected, citation inflation should not be a major concern here.
} 
somewhat closer in principle to the methodology employed by Liebowitz and Palmer (1984), Kalaitzidakis et. al. (2003, 2010) or Palacios-Huerta and Volij (2004) where citations by important journals are more valuable. The difference is that - since we do not count the citations to working paper series - importance is given exogenously by the size of the monetary area. The second column in Table 2 exemplifies the weights that were used for the GDP weighted ranking. ${ }^{5}$ Note that the de facto weight of an area typically differs from the purely economic weight. For instance, Sveriges Riksbanken punches above the economic weight of Sweden because - by having a higher citation average - their research staff contributed with more citations to our database. The largest de facto weights were those of the Eurozone (34.8\%), the United States (33.3\%), Japan (7.4\%) and the United Kingdom (5.4\%).

\section{Global Rankings}

Table 3 lists the 30 top outlets of the global journal ranking of central banks. 6 Note that the ranking of the top 4 outlets is unchanged irrespective of whether we use the GDP weighted ranking or the equal weights ranking: the Journal of Monetary Economics, the American Economic Review, the Journal of Money, Credit and Banking and the Journal of Finance clearly stand out as the top journals. Furthermore, while the Journal of Monetary

\footnotetext{
${ }^{5}$ The de facto weight is given by the product of the GDP weight (or economic weight) by the citations/working paper index of the monetary area divided by the average citations/working paper count of the world.

${ }^{6}$ The complete ranking of the 431 outlets can be obtained upon request.
} 
Economics receives an average of 0.98 citations to recent articles per working paper, the American Economic Review receives 0.84. No other journal scores above 0.50. The Journal of Financial Economics ranks 5th in the GDP weighted ranking, in great part due to its strong showing in the U.S., where it shows up as 2nd, and the Eurozone, where it appears as 7th.

The last column of Table 3 specifies how many positions each outlet gained relative to the academic ranking of Kalaitzidakis et. al. (2010). It is clear that in most cases the change in positions relative to the academic ranking is very significative. The absolute change in positions lies below 3 for only 2 of the top 30 journals. Moreover, the top 30 outlets include 5 that were not analyzed by those authors. Important differences in the relative performance of general journals are apparent: for instance, while the Journal of the European Economic Association climbs 10 positions to make it into the top 10, the Review of Economic Studies, the European Economic Review and the Journal of Economic Theory drop 14, 12 and 20 positions, respectively. Moreover, some journals that are listed among the top 30 in Kalaitzidakis et. al. (2010) do not make it into the top 30 in the journal ranking of central bankers. These include the Journal of Economic Literature, Economics Letters and the Journal of Development Economics.

It should be noted that some of the outlets that were analyzed in this study are relatively new. For instance, the topical International Journal of Central Banking appears on position 20, right behind the Review of Economic Studies, even though it only started to be published in 2005. A counterfactual exercise allows one to conclude that - had it started publishing papers of the 
same impact in 2001 - it would have climbed to position 12 in the ranking, between the Journal of Econometrics and Econometrica. On the other hand, the American Economic Journal: Macroeconomics only started to be released in 2009, so that it should be no surprise that it does not feature among the top 30. The analysis did cover the first 10 years of existence of the B.E. Journal: Macroeconomics, that makes it to position 31.

Another aspect that is remarkable is the relatively weak performance of journals devoted to the understanding of the labor markets. Even more so if one considers that - at least theoretically - frictions in the labour market can provide a rationale for an active monetary policy. Indeed, none of the field journals in this area makes it into the list of top central banking journals. Labour Economics shows up in position 48, while the Journal of Labor Economics appears in position 64. Only in Denmark does one of them appear in the list of top journals of Table 1.

To conclude, it is important to emphasize that the methodology to construct this ranking included citations to all journals, and not just the top ones. This means that there is no risk that the inclusion of a journal from a different area of knowledge would alter the ordering of the rankings. In this sense the ranking presented here is more robust than previous ones. Finally, our analysis allows us to establish that there is considerable concentration of citations in the top economic outlets: overall, the top 30 journals received two thirds of the citations from working papers, while the remaining 401 journals accounted for the other third of citations. 


\section{References}

[1] Bussiere, M. and L. Stracca (2010) A Decade (and a Financial Crisis) after Blinder. The Interaction Between Researchers and Policy-Makers in Central Banks. European Central Bank. Working Paper no. 1260.

[2] Garfield, E. (1972) Citation Analysis as a Tool in Journal Evaluation. Science, vol. 178, 471-479.

[3] Kalaitzidakis, T., P.T. Mamuneas and T. Stengos (2003) Rankings of Academic Journals and Institutions in Economics. Journal of the European Economic Association, vol. 1 (6), 1346-1366.

[4] Kalaitzidakis, T., P.T. Mamuneas and T. Stengos (2010) An Updated Ranking of Academic Journals in Economics. University of Guelph. Working paper 10-09.

[5] Kodrzycki, Y.K. and P. Yu (2006) New Approaches to Ranking Economic Journals. Contributions to Economic Analysis and Policy, vol. 5, art. 24.

[6] Laband, D. and Piette, M. (1994) The Relative Impact of Economic Journals. Journal of Economic Literature, vol. 32, 640-666.

[7] Liebowitz, S. J. and Palmer, J. P. (1984) Assessing the Relative Impacts of Economic Journals. Journal of Economic Literature, vol. 22 (1), 77-88.

[8] Palacio-Huerta, I. and O. Volij (2004) The Measurement of Intellectual Influence. Econometrica, vol. 72, 963-977. 
TABLE 1 - Country Rankings

\begin{tabular}{|c|c|c|c|c|c|c|c|c|c|}
\hline \multicolumn{2}{|l|}{ U.S.A. } & \multicolumn{2}{|l|}{ EUROZONE } & \multicolumn{2}{|l|}{ JAPAN } & \multicolumn{2}{|l|}{ U.K. } & \multicolumn{2}{|l|}{ BRAZIL } \\
\hline $1 \mathrm{AER}$ & 1.03 & $1 \mathrm{~J}$ MONET ECON & 1.80 & $1 \mathrm{~J}$ MON CRED B & 0.69 & $1 \mathrm{~J}$ MONET ECON & 1.71 & $1 \mathrm{~J}$ BANK FIN & 0.97 \\
\hline 2 J FINANC ECON & 0.70 & 2 AER & 0.87 & 2 AER & 0.54 & 2 AER & 1.18 & 2 J ECONOMETRICS & 0.63 \\
\hline 3 J FINANCE & 0.67 & 3 J ECON DYN CON & 0.70 & REV ECON DYN & 0.54 & 3 J MON CRED B & 0.68 & 3 J INT MON FIN & 0.33 \\
\hline 4 R FIN STUD & 0.57 & 4 J FINANCE & 0.67 & 4 J MONET ECON & 0.46 & 4 J ECON DYN CON & 0.61 & 4 J MONET ECON & 0.30 \\
\hline 5 J MONET ECON & 0.53 & 5 J MON CRED B & 0.60 & J JPN INT ECON & 0.46 & $5 \mathrm{~J}$ INT ECON & 0.57 & J INT ECON & 0.30 \\
\hline $6 \mathrm{Q} J \mathrm{ECON}$ & 0.40 & 6 J EUR ECON ASS & 0.57 & 6 J ECON DYN CON & 0.38 & 6 REV ECON STUD & 0.54 & $6 \mathrm{~J} \mathrm{MON} \mathrm{CRED} \mathrm{B}$ & 0.27 \\
\hline ECONOMETRICA & 0.40 & 7 J FINANC ECON & 0.43 & I J CENTRAL BANK & 0.38 & 7 J POLIT ECON & 0.39 & J FIN STABILITY & 0.27 \\
\hline 8 J POLIT ECON & 0.37 & 8 ECON POLICY & 0.37 & 8 JEEA, etc & 0.23 & $8 \mathrm{~J}$ EUR ECON ASS & 0.36 & EUR J OPER RES & 0.27 \\
\hline \multicolumn{2}{|l|}{ CANADA } & \multicolumn{2}{|l|}{ AUSTRALIA } & \multicolumn{2}{|l|}{ MEXICO } & \multicolumn{2}{|l|}{ SOUTH KOREA } & \multicolumn{2}{|l|}{ TURKEY } \\
\hline $1 \mathrm{AER}$ & 0.87 & $1 \mathrm{~J}$ MONET ECON & 2.00 & $1 \mathrm{AER}$ & 0.65 & $1 \mathrm{AER}$ & 0.67 & $1 \mathrm{~J}$ MONET ECON & 0.89 \\
\hline 2 J MONET ECON & 0.77 & 2 J MON CRED B & 1.00 & 2 J ECONOMETRICS & 0.50 & 2 REV INT POL EC & 0.56 & 2 AER & 0.58 \\
\hline 3 J FINANCE & 0.63 & 3 J INT ECON & 0.50 & 3 Q J ECON & 0.45 & 3 J BANK FIN & 0.44 & 3 J INT ECON & 0.53 \\
\hline 4 ECONOMETRICA & 0.60 & ECON RECORD & 0.50 & 4 J POLIT ECON & 0.40 & 4 BEJ: MACRO & 0.33 & 4 J EUR ECON ASS & 0.42 \\
\hline 5 J MON CRED B & 0.43 & 5 BEJ: MACRO & 0.38 & J PUBLIC ECON & 0.40 & J MON CRED B & 0.33 & 5 J POLIT ECON & 0.32 \\
\hline 6 R FIN STUD & 0.33 & Q J ECON & 0.38 & $6 \mathrm{~J}$ MON CRED B & 0.35 & REV ECON STAT & 0.33 & J MON CRED B & 0.32 \\
\hline J INT ECON & 0.33 & J POLIT ECON & 0.38 & J MONET ECON & 0.35 & BROOKINGS P & 0.33 & IKTISADI & 0.32 \\
\hline REV ECON STUD & 0.33 & J ECONOMETRICS & 0.38 & REV EC STAT, etc & 0.35 & CHINA SOCIAL SC & 0.33 & 8 INT ECON REV & 0.26 \\
\hline \multicolumn{2}{|l|}{ SWITZERLAND } & \multicolumn{2}{|l|}{ SWEDEN } & \multicolumn{2}{|l|}{ POLAND } & \multicolumn{2}{|l|}{ NORWAY } & \multicolumn{2}{|l|}{ DENMARK } \\
\hline $1 \mathrm{AER}$ & 1.47 & $1 \mathrm{AER}$ & 1.83 & $1 \mathrm{AER}$ & 0.63 & $1 \mathrm{AER}$ & 0.83 & $1 \mathrm{QJECON}$ & 0.57 \\
\hline 2 J MONET ECON & 1.05 & J MONET ECON & 1.83 & J FINANCE & 0.63 & 2 J MONET ECON & 0.67 & 2 J MONET ECON & 0.43 \\
\hline 3 J POLIT ECON & 0.79 & 3 J MON CRED B & 1.00 & $3 \mathrm{~J}$ MONET ECON & 0.50 & 3 J FINANCE & 0.63 & J MON CRED B & 0.43 \\
\hline 4 J FINANCE & 0.68 & 4 I J CENTRAL BANK & 0.67 & J FINANC ECON & 0.50 & 4 J MON CRED B & 0.50 & J ECON PERSPECT & 0.43 \\
\hline 5 J MON CRED B & 0.63 & 5 J POLIT ECON & 0.58 & J EUR ECON AS & 0.50 & 5 R FIN STUD & 0.37 & J FINANC ECON & 0.43 \\
\hline Q J ECON & 0.63 & $6 \mathrm{~J}$ EUR ECON ASS & 0.50 & FINANCE \& DEV & 0.50 & $6 \mathrm{~J}$ BUS ECON STAT & 0.33 & 6 INT ECON REV & 0.29 \\
\hline 7 J INT ECON & 0.58 & EUR J POL ECON & 0.50 & 7 J INT ECON & 0.38 & J FINANC ECON & 0.33 & LABOUR ECON & 0.29 \\
\hline 8 R FIN STUD & 0.42 & $8 \mathrm{~J}$ ECON DYN CON & 0.42 & BEJ: MACRO, etc & 0.38 & JEDC, etc & 0.33 & BEJ: MACRO, etc & 0.29 \\
\hline
\end{tabular}




\section{TABLE 2 - Citations Pattern and Weights}

\begin{tabular}{|c|c|c|c|c|}
\hline central bank & monetary area & citations/working paper & economic weight & de facto weight \\
\hline 1 Sveriges Riksbank & Sweden & 14.9 & 0.010 & 0.014 \\
\hline 2 European Central Bank & Eurozone & 13.5 & 0.274 & 0.348 \\
\hline 3 Norges Bank & Norway & 12.0 & 0.009 & 0.011 \\
\hline 4 Swiss National Bank & Switzerland & 12.0 & 0.012 & 0.013 \\
\hline 5 Bank of Mexico & Mexico & 11.7 & 0.023 & 0.025 \\
\hline
\end{tabular}


TABLE 3 - The Journal Ranking of Central Bankers (2001-2010)

\begin{tabular}{|c|c|c|c|c|}
\hline & $\begin{array}{c}\text { impact } \\
\text { (weighted by GDP) }\end{array}$ & $\begin{array}{c}\text { impact } \\
\text { (equal weights) }\end{array}$ & $\begin{array}{c}\text { ranking } \\
\text { (equal weights) }\end{array}$ & $\begin{array}{l}\text { positions gained } \\
\text { rel. to KMS (2010) }\end{array}$ \\
\hline $1 \mathrm{~J}$ MONETARY ECON & 0.983 & 0.894 & 1 & 5 \\
\hline 2 AM ECON REV & 0.838 & 0.770 & 2 & -1 \\
\hline 3 J MONEY CREDIT BANK & 0.475 & 0.508 & 3 & 18 \\
\hline 4 J FINANCE & 0.474 & 0.331 & 4 & NR \\
\hline 5 J FINANC ECON & 0.381 & 0.197 & 13 & 10 \\
\hline $6 \mathrm{~J}$ ECON DYN CONTROL & 0.310 & 0.224 & 11 & 22 \\
\hline 7 Q J ECON & 0.309 & 0.297 & 6 & -5 \\
\hline $8 \mathrm{~J}$ POLIT ECON & 0.290 & 0.301 & 5 & -4 \\
\hline 9 J EUR ECON ASSOC & 0.287 & 0.245 & 8 & 10 \\
\hline 10 R FIN STUDIES & 0.266 & 0.192 & 14 & NR \\
\hline $11 \mathrm{~J}$ ECONOMETRICS & 0.254 & 0.245 & 9 & 3 \\
\hline 12 ECONOMETRICA & 0.198 & 0.168 & 16 & -9 \\
\hline 13 J INT ECON & 0.196 & 0.275 & 12 & -1 \\
\hline 14 REV ECON STAT & 0.194 & 0.208 & 10 & -7 \\
\hline 15 J BANK FINANC & 0.192 & 0.228 & 7 & 41 \\
\hline 16 J BUS ECON STAT & 0.181 & 0.129 & 20 & 14 \\
\hline 17 REV ECON DYNAM & 0.164 & 0.129 & 21 & 7 \\
\hline 18 J ECON PERSPECT & 0.160 & 0.146 & 18 & -7 \\
\hline 19 REV ECON STUD & 0.159 & 0.175 & 15 & -14 \\
\hline 20 INT J CENT BANKING & 0.156 & 0.154 & 17 & NR \\
\hline $21 \mathrm{~J}$ FIN INTERMED & 0.140 & 0.102 & 27 & NR \\
\hline 22 ECONOMIC JOURNAL & 0.139 & 0.117 & 25 & -12 \\
\hline 23 J APP ECONOM & 0.127 & 0.109 & 26 & 9 \\
\hline 24 EUR ECON REV & 0.118 & 0.120 & 24 & -8 \\
\hline 25 J INT MONEY FINANCE & 0.115 & 0.128 & 22 & NR \\
\hline 26 ECON POLICY & 0.108 & 0.053 & 37 & 16 \\
\hline 27 J PUBLIC ECON & 0.108 & 0.049 & 40 & -18 \\
\hline $28 \mathrm{~J}$ ECON THEORY & 0.105 & 0.098 & 28 & -20 \\
\hline 29 INT ECON REV & 0.098 & 0.122 & 23 & -11 \\
\hline 30 BROOKINGS PAP ECO AC & 0.097 & 0.078 & 30 & 3 \\
\hline
\end{tabular}




\section{Appendix: Working Paper Series}

\begin{tabular}{llll}
\hline central bank & source & quantity & numbers \\
\hline Bank of Canada & working papers & 30 & $2010-11-2010-40$ \\
Bank of England & BoE working papers & 28 & $379-407$ \\
Bank of Japan & BoJ working paper series & 13 & $10-\mathrm{E}-01-10-\mathrm{E}-13$ \\
Bank of Korea & BoK working papers & 9 & $65-73$ \\
Bank of Mexico & working papers & 20 & $2010-01-2010-20$ \\
Central Bank of Brazil & working papers & 30 & $201-230$ \\
Central Bank of the Republic of Turkey & working papers & 19 & $10 / 01-10 / 09$ \\
Danmarks Nationalbank & working papers & 8 & $64-71$ \\
European Central Bank & ECB working paper series & 30 & $1254-1283$ \\
Federal Reserve Bank & staff reports/research paper series & 30 & $451-480$ \\
National Bank of Poland & NBP working papers & 8 & $71-78$ \\
Norges Bank & working papers 2010 & 30 & $2-31$ \\
Reserve Bank of Australia & research discussion papers & 8 & $2010-01-2010-08$ \\
Sveriges Riksbank & working paper series 2010 & 12 & $236-247$ \\
Swiss National Bank & SNB working papers & 19 & $2010-01-2010-19$ \\
\hline
\end{tabular}

1) paper 68 was not listed for download at the time of writing 